\title{
Feeding of Calcium and Protein Macroparticle or Microparticle with Bitter Mustard Root on Intestinal Bacteria Population and Nutrient Intake in Quail
}

\author{
Lilik Krismiyanto $^{1}$, Nyoman Suthama ${ }^{1}$, Vitus Dwi Yunianto ${ }^{1}$, Fajar Wahyono ${ }^{1}$, Citra \\ Ardelia $^{2}$ and Ryan Zafi Fawwaz ${ }^{2}$ \\ ${ }^{1}$ Department of Animal Science, Faculty of Animal and Agriculture Sciences, \\ Universitas Diponegoro, Semarang, Indonesia \\ ${ }^{2}$ Study Program of Animal Science, Faculty of Animal and Agriculture Sciences, \\ Universitas Diponegoro, Semarang, Indonesia \\ Corresponding author : Lilik Krismiyanto \\ Email : lilikkrismiyanto@gmail.com
}

\begin{abstract}
This study aims to feeding of protein source feed ingredients in macroparticle or microparticles with the addition of bitter mustard root to the small intestinal bacteria population and nutrient intake in quails. The experimental livestock used by the layer phase quail were 200 birds with an average weight of $149 \pm 10.88 \mathrm{~g}$, protein feed ingredients in the form of soybean meal and fish meal, calcium comes from eggshells and mustard root powder as a prebiotic. The research design was a completely randomized design with 4 treatment and 5 replaice (each 10 bird). The treatment were $\mathrm{P} 1=$ Feed with protein and calcium macroparticles; $\mathrm{P} 2=$ Feed with protein and calcium microparticles; P3 = Feed with protein and calcium macroparticles + bitter mustard root powder 1,2\% dan $\mathrm{P} 4=$ Feed with protein and calcium microparticles + bitter mustard root powder $1,2 \%$. The parameters measured were population of lactic acid bacteria, coliform, $\mathrm{pH}$, protein and calcium intake. Data were analyzed using analysis of variance (Anova) and different test (Duncan) on 5\% level. The results showed that the use of rations with protein and calcium feed ingredients in macroparticles or microparticles with the addition of bitter mustard root powder had a significant effect $(p<0,05)$ on population of small intestine bacteria and nutrient intake. The use of protein and calcium microparticles with the addition of $1.2 \%$ bitter mustard root powder $(\mathrm{P} 4)$ was able to increase the population of lactic acid bacteria and nutrient intake (protein and calcium) and decreased coliform population and small intestine $\mathrm{pH}$ compared to other treatments (P1-P3). The conclusion is feeding of protein and calcium microparticles and addition of $1.2 \%$ bitter mustard root powder could increase the population of lactic acid bacteria, protein and calcium intake and reduce the coliform population and the $\mathrm{pH}$ of the small intestine.
\end{abstract}

Keywords : bitter mustard root, broiler chicken, microparticle, nutrient intake, small intestine bacteria. 


\section{Introduction}

The poultry industry sector, particularly the ration production sector, has increased due to the poultry sector, such as broilers, layers, local chickens, broiler or laying ducks, quails and so on. The company produces rations in accordance with the increase in ration requirements by breeders and public awareness of consuming protein sources, especially meat and eggs. The Central Statistics Agency (2018) reports that broiler chicken meat consumption is $11.5 \mathrm{~kg} /$ capita / year and egg consumption is 6.53 $\mathrm{kg} /$ capita / year. The high demand for meat and egg products has implications for the number of poultry populations that are commercialized to produce meat or eggs. According to the Central Statistics Agency (2018), broiler chicken meat production reached 3,565,495 tons, above the national need of 3,047,676 tons, while egg production was $1,756,691$ tons above the national need of 1,703,550 tons. This has led to an increase in the poultry population and rations to meet demand.

Egg production in broilers nationally contributes the most compared to eggs in other poultry. Egg production in laying hens is of great interest to the public in processing food products, but on the one hand, quail eggs in a separate segment have high potential. Quail ( coturnix coturnix ) japonica is one of poultry commodities that have an important role and prospect to produce eggs (Patanggara et al., 2011). Quail can also be as gemak (Javanese) and quail is considered as wild bird (Patanggara et al., 2011). Until now, quail breeders still rely on rations from the manufacturer. Not all manufacturers' rations process feed ingredients with the same particle size. Ingredients, if the particle size is reduced, especially for protein and calcium sources, can help optimize nutrient absorption. Particle size is currently widely known using microparticles of feed ingredients. Microparticles are a decrease in particle size which causes an increase in the number of particles and surface area per unit volume which allows higher absorption by digestive enzymes (Huang and Stein, 2016).

For feed ingredients, especially protein and calcium sources, the particle size is reduced so that the surface area is high and is easily absorbed by the body. The feed ingredients commonly used by microparticles come from soybean meal, fish meal and egg shells. Soybean meal and fish meal are commonly used in the preparation of rations, so these feed ingredients are suitable for microparticles. Suthama and Wibawa (2018) state that microparticle protein obtained from fish meal and soybean meal by ultrasonic treatment is a way to meet the goal of increasing the use of protein and amino acids. The by-products of the bakery industry produce a lot of egg shells which can be used as raw material for organic calcium sources. The results of the research by Kismiati et al (2012) showed that the use of eggshells as a source of organic calcium increased the production of laying hens compared to chickens given limestone.

The use of protein and calcium microparticles in the preparation of rations so that an increase occurs can be added to additives from prebiotics. The prebitok added to the ration was bitter mustard root flour. Bitter mustard root contains a prebiotic, namely inulin. Inulin is used in industry as food and feed for livestock. Inulin is very beneficial for beneficial bacteria in the digestive tract. Inulin as a substrate is utilized by beneficial bacteria, then fermentation occurs so that organic acids (acetic, propionic and butyric) change the $\mathrm{pH}$ of the small intestine to low. The low hydrogen potential inhibits the 
growth of pathogenic bacteria and increases the action of proteases. High protease action to hydrolyze protein and calcium. Protein and calcium are linked together in the absorption process through a compound called "calcium-binding protein (CaBP)" (Saputra et al 2020).

Based on the description above, it aims to examine microparticle feed ingredients, sources of protein and calcium in rations with the addition of bitter mustard root to the small intestine bacteria population and nutrient intake. The benefit is that knowledge is obtained about the use of rations with protein and calcium feed ingredients and bitter mustard root flour.

\section{Materials and Methods}

\section{Research Experiment}

The experimental livestock used by the quail (Cortunix cortunix japonica) layer phase from the age of 6 weeks were 200 birds with an average body weight of $149 \pm$ 10.88 g. Research rations were prepared with various types of feed ingredients including milled corn, bran, soybean meal, fish meal, eggshell flour, vitamins, minerals, lysine and methionine. The composition and levels of nutrient rations can be presented in Table 1.

Table 1. Compotition of feed ingredients and nutrien content

\begin{tabular}{|c|c|c|}
\hline \multirow{2}{*}{ Feed Ingredients } & \multicolumn{2}{|c|}{ Compotition } \\
\hline & Macroparticle & Microparticle \\
\hline & \multicolumn{2}{|c|}{----------------------\%"----------------- } \\
\hline Yellow corn & 51.07 & 51.07 \\
\hline Bran & 4.60 & 4.60 \\
\hline Soybean meal & 24.00 & - \\
\hline Micro soybean meal & - & 24.00 \\
\hline Fish meal & 10.00 & - \\
\hline Micro fish meal & - & 10.00 \\
\hline Egg shell & 7.00 & - \\
\hline Micro egg shell & - & 7.00 \\
\hline Vitamins dan Minerals & 2.00 & 2.00 \\
\hline Vegetable oil & 1.00 & 1.00 \\
\hline Lysine & 0.08 & 0.08 \\
\hline Methionine & 0.25 & 0.25 \\
\hline Total & 100.00 & 100.00 \\
\hline \multicolumn{3}{|l|}{ Nutrient content : } \\
\hline Energi Metabolis $(\mathrm{kkal} / \mathrm{kg})^{*}$ & $2,840.78$ & $2,838.72$ \\
\hline Crude Protein $(\%)^{* *}$ & 19.15 & 19.10 \\
\hline Crude Fat $(\%)^{* *}$ & 4.86 & 4.65 \\
\hline Crude Fiber $(\%)^{* *}$ & 4.95 & 4.41 \\
\hline Calsium $(\%)^{* *}$ & 4.05 & 4.06 \\
\hline Phosphor $(\%)^{* *}$ & 0.87 & 0.87 \\
\hline
\end{tabular}


The preparation of microparticles of feed ingredients for protein sources (soybean meal and fish meal) and calcium (egg shell) is carried out by refining soybean meal and fish meal. Cleaning of egg shells from dirt or liquid contents of the eggs using clean running water. Dry the clean eggshell, then when it's dry, grind it using a grinder. The three ingredients have been mashed and then sifted using a 100 mesh (150 um) sieve. The results of the material that pass the filter are then carried out by the sonification process. The ingredients are dissolved using aquadest with a ratio of 1:10 and added 10 $\mathrm{ml}$ of virgin coconut oil (VCO), then homogenized with a stirring rod. Furthermore, the material is put into a sonifier with a temperature setting of $370 \mathrm{C}, 50 \mathrm{~Hz}$ and for 60 minutes. Then, the material is dried under the sun and refined again.

The process of making bitter mustard root flour is by washing the roots thoroughly using clean running water, then cutting the roots into small pieces and drying them in the sun. If it is dry then grind it using a blender and the ingredients are sifted to get a fine flour.

\section{Experiment Design}

The study was arranged using a completely randomized design with 4 treatments and 5 replications, each experimental unit filled with 10 animals. The following treatments are applied:

$\mathrm{P} 1=$ ration with protein and calcium macroparticles

$\mathrm{P} 2=$ diet with protein and calcium microparticles

$\mathrm{P} 3=$ ration with protein and calcium macroparticles $+1,2 \%$ bitter mustard root

$\mathrm{P} 4=$ ration with microparticles protein and calcium $+1,2 \%$ bitter mustard root

Parameters and Statistical Analysis

Data were measured at 4 weeks of maintenance or 10 weeks of age, layer-phase quails were given protein and calcium microparticle rations with the addition of bitter mustard root flour. The parameters measured included the population of lactic acid bacteria, coliform, small intestine $\mathrm{pH}$, protein and calcium intake.

Data collection for the population of lactic acid bacteria, coliform and the $\mathrm{pH}$ of the small intestine was that each experimental unit was taken 1 head to be cut first. The quail has been cut, then a necropsy of the abdominal cavity is performed. Furthermore, the digestive tract is removed and trimmed according to the order of the digestive organs. The digestive organs, especially the small intestine, are first measured for $\mathrm{pH}$ using a $\mathrm{pH}$ meter with an accuracy of 0.1 . Next, the digesta starts from the duodenal tract until the ileum is removed by the digesta and placed in a small tube. Digesta excretion process from the small intestine and $\mathrm{pH}$ measurement at room temperature (25-270C). The digesta is collected in a small tube, then the total bacteria test is carried out using the total plate count method. The calculation of bacteria, both lactic acid and coliform, is based on Fardiaz (1993).

Measurement of protein and calcium intake was measured by the total excreta collection method. The total collection of excreta was carried out by measuring 10 individuals in each experimental unit. The total collection process lasts for 4 days. The excreta was tested for protein and calcium and the calculation of nutrient intake. 
The data were processed using analysis of variance (ANOVA) and compared to the results of $\mathrm{F}$ count with $\mathrm{F}$ table at $5 \%$ level, if there is an influence then further analysis is

\section{Results and Discussion}

The results showed that the use of rations with protein and calcium macroparticles or microparticles with the addition of bitter mustard root flour had a significant effect $(\mathrm{p}<0.05)$ on the population of lactic acid bacteria (LAB), coliform, small intestine $\mathrm{pH}$, protein and calcium intake. Based on the Duncan significant difference test at $5 \%$ level, the use of protein and calcium microparticle rations with the addition of $1.2 \%$ bitter mustard root flour (P4) was able to increase the LAB and coliform population in the small intestine compared to other treatments (P1-P3). Treatment of $\mathrm{P} 4$ on the $\mathrm{pH}$ of the small intestine, protein and calcium intake was higher than the use of rations without protein and calcium microparticles (P1), but not significantly different from the use of protein and calcium microparticles (P2) and the use of rations without protein and calcium microparticles with the addition of $1,2 \%$ mustard root powder (P3).

Table 2. Bacteria Lactic Acid Population Paramater, Coliform, pH, Protein and Kalsium Intake

\begin{tabular}{lcccc}
\hline \multicolumn{1}{c}{ Parameter } & P1 & P2 & P3 & P4 \\
\hline Population & & & & \\
BAL $\left(10^{10}\right)$ & $6.54^{\mathrm{d}}$ & $7.53^{\mathrm{c}}$ & $8.39^{\mathrm{b}}$ & $9.25^{\mathrm{a}}$ \\
Coliform $\left(10^{4}\right)$ & $14.66^{\mathrm{a}}$ & $13.33^{\mathrm{b}}$ & $11.99^{\mathrm{c}}$ & $10.92^{\mathrm{d}}$ \\
Small intestine $\mathrm{pH}$ & $6.72^{\mathrm{b}}$ & $6.52^{\mathrm{ab}}$ & $6.52^{\mathrm{ab}}$ & $6.48^{\mathrm{a}}$ \\
& & & & \\
Intake & & & \\
Protein $(\mathrm{g})$ & $2.76^{\mathrm{b}}$ & $2.84^{\mathrm{ab}}$ & $2.93^{\mathrm{ab}}$ & $3.05^{\mathrm{a}}$ \\
Calsium $(\mathrm{g})$ & $0.28^{\mathrm{c}}$ & $0.34^{\mathrm{bc}}$ & $0.40^{\mathrm{b}}$ & $0.53^{\mathrm{a}}$ \\
\hline abcd Superscript on the same row show significant $(\mathrm{p}<0,05)$. & &
\end{tabular}

${ }^{\text {abcd }}$ Superscript on the same row show significant $(\mathrm{p}<0,05)$.

\section{Lactic Acid Bacteria Population, pH dan Small Intestine Coliform}

The use of protein and calcium microparticle rations with the addition of $1.2 \%$ mustard root powder (P4) was able to increase the small intestine LAB population. Sources of protein that were carried out by microparticles were soybean meal and fish meal, while the source of calcium came from eggshell flour. Microparticles are a source of protein and calcium which can be optimally utilized in the small intestine. The presence of protein and calcium microparticles can be hydrolyzed and absorbed directly. Moreover, the addition of $1.2 \%$ bitter mustard root flour as a prebiotic source can help in increasing the LAB population endogenously in the small intestine. Bitter mustard root flour as a prebiotic or having inulin levels in the digestive tract can provide a substrate for $\mathrm{LAB}$ and $\mathrm{LAB}$ reproduction by fermentation. The result of the fermentation process produced by LAB is in the form of short chain fatty acids (acetic, propionic and butyric acids) which change the environmental $\mathrm{pH}$ conditions in the small intestine to decrease. Treatment $\mathrm{P} 4$ can change the condition of small intestine $\mathrm{pH}$ to decrease compared to treatment P1. This is due to the role of inulin from mustard root 
flour which provides substrate for LAB and undergoes fermentation and lowers the $\mathrm{pH}$ of the small intestine. Rebole et al. (2010) reported that adding $20 \mathrm{~g} / \mathrm{kg}$ of inulin in broiler rations was able to increase the Bifidobacter and Lactobacillus population in the small intestine. Samanta et al. (2013) stated that intestinal bacteria are sensitive to $\mathrm{pH}$ and its reduction requires changes in bacterial composition, such as inhibited proliferation of pathogenic Salmonella or E. coli.

The addition of $1.2 \%$ bitter mustard root flour added to the ration of protein and calcium microparticles (P4) had an impact on the $\mathrm{pH}$ of the small intestine which resulted in stunted coliform population growth. Low $\mathrm{pH}$ sensitivity interferes with the growth of coliform bacteria unable to reproduce. The low hydrogen potential can activate the protease in hydrolyzing protein so that the protease action increases and changes the $\mathrm{pH}$ of the small intestine. Nabizadeh (2012) reported that the addition of $0.5-1 \%$ inulin supplementation in the ration can reduce the $\mathrm{pH}$ of the ileum and Escherichia coli population. Inulin-type fructans can be fermented by intestinal bacteria to produce acetate, propionate and butyrate which have important physiological functions. $\beta(2 \rightarrow 1)$ glycosidic bonds, inulin are resistant to digestive enzymes and promote bacterial growth, thereby promoting health and suppressing the growth of pathogenic bacteria. Samanta et al. (2013) stated that inulin as a prebiotic to inhibit salmonella growth in chickens and the inclusion of oligofructose in chicks ration was substantially activated.

\section{Protein and Calcium Intake}

The use of protein and calcium microparticles rations with the addition of $1.2 \%$ bitter mustard root flour $(\mathrm{P} 4)$ on protein and calcium intake was higher than the ration treatment without microparticles (P1). The absorbed protein is then metabolized and cannot be separated from the LAB population and $\mathrm{pH}$. Because LAB with low $\mathrm{pH}$ supports protease to hydrolyze protein. The smaller the protein particle size, the more the protein absorption process increases. Suthama et al. (2019) stated that the reduction in particle size correlates with an increase in the number of particles as well as the surface area per unit volume and allows greater access to digestive enzymes as well as digestive enzyme activity with a smaller feed particle size allowing for increased nutrition, especially protein. The protein intake in P2 and P3 was not different because the ration in P2 was in the form of microparticles, while in P3 the rations were not microparticles but added $1.2 \%$ bitter mustard root flour. This indicates that the ration without microparticles with the addition of $1.2 \%$ bitter mustard root flour can increase protein intake, as well as treatment P2. Increased protein digestibility with single microparticle feed ingredients (soybean meal or fish meal) is an important nutrient, especially protein in increasing body weight. Diets that do not experience microparticles are seen from the lower digesta rate compared to rations containing microparticles. Cholis et al. (2018) stated that the increase in protein intake was supported by a slower rate of digestion because the digestion was spent longer in the intestine so that protein digestibility increased.

Rations of protein and calcium microparticles with $1.2 \%$ bitter mustard root flour (P4) on calcium intake were higher than rations without microparticles with $1.2 \%$ bitter mustard root flour (P3). The results of this study indicate that the role of protein and calcium microparticles is faster hydrolyzed than ordinary protein and calcium (without micro). Although the presence of inulin as a LAB substrate and lowering the $\mathrm{pH}$ of the 
small intestine, the process of hydrolysis of protein and calcium in the micro form is higher in absorption. The value of protein intake is in line with the increased calcium intake. According to Santia et al. (2019) stated that calcium is always related to a protein which is often called $\mathrm{Ca}$ binding protein $(\mathrm{CaBP})$. The formation of bonds and absorption of $\mathrm{CaBP}$ is more effective with the use of eggshell flour made by microparticles. Eggshell flour is an organic calcium which has high bioavailability for the formation of quail eggs. Samanta et al. (2013) stated that the potential of acid hydrogen could increase mineral solubility and facilitate higher mineral absorption, especially butyrate more effectively than acetate for higher $\mathrm{Ca}$ absorption.

\section{Conclusion}

The use of rations with protein and calcium microparticles and the addition of $1.2 \%$ bitter mustard root flour can increase the population of lactic acid bacteria, protein and calcium intake and reduce the coliform population and $\mathrm{pH}$ of the small intestine in layer-phase quail.

\section{References}

Badan Pusat Statistik. Produksi Telur Ayam Menurut Provinsi. Badan Pusat Statistik: Jakarta, 2018.

Bolton, W. Poultry Nutrition. MAFF Bulletin, No.174.. HMSO: London, 1967.

Cholis A, Suthama N, Sukamto B. Feeding microparticle protein diet combined with Lactobacillus sp. on existence of intestinal bacteria and growth of broiler chickens. J. Indonesian Trop. Anim. Agric. 43(3):265-271, 2018.

Fardiaz, S. Analisis Mikrobiologi Pangan. Raja Grafindo Persada: Jakarta, 1993.

Gaspersz, V. Metode Perancangan Percobaan. CV Armico: Bandung, 1991.

Huang, C., and H. H. Stein. Amino aciddigestibility in soy protein concentrate withdifferent particle sizes fed to weanling pigs. Pig Progress Res. Report. P. 3233, 2016.

Kismiati S, T. Yuwanta, Z. Zuprizal, and S. Supadmo. The performance of laying hens fed different calcium source. J. the Indonesian Trop. Anim. Agric., 37(4):263$270,2012$.

Nabizadeh, A. The effect of inulin on broiler chicken intestinal microflora, gut morphology, and performance. J. Anim. and Feed Sci. 21:725-734, 2012.

Patanggara, E. U. H., V. D. Yunianto, B. Sukamto, and L. Krismiyanto. 2019. The use of calcium in quails during egg hatching phase by adding yacon leaf powder (Smallantus sonchifolius). Bantara J. Anim. Sci. 1(1) : 21-27.

Rebolé A, L. .T Ortiz, M. L. Rodríguez, C. Alzueta, J. Treviño, and S. Velasco. Effects of inulin and enzyme complex, individually or in combination, on growth performance, intestinal microflora, cecal fermentation characteristics, and jejunal 
histomorphology in broiler chickens fed a wheat and barley-based diet. Poultry Science 89: 276-278, 2010.

Samanta, A. K., N. Jayapal, S. Senani, A. P. Kolte, and M. Sridhar. Prebiotic inulin: useful dietary adjuncts to manipulate the livestock gut microflora. Braz. J. Microb. 44: 1- 14, 2013.

Santia, H. E., N. Suthama, dan B. Sukamto. 2019. Pemanfaatan protein pada ayam broiler yang diberi ransum menggunakan kalsium mikropartikel cangkang telur dengan suplementasi asam sitrat. J. Sain Pet. Indonesia 14(3): 252-258, 2019.

Saputra, Y. A., N. Suthama, and B. Sukamto. Feeding diets composed of low level microparticle protein derived from fish and soybean meals and using organic calcium added with Lactobacillus acidophilus or citric acid on intestinal condition and performance of broilers. Livestock Res. for Rural Develop. 32(4), 2020.

Suthama, N., B. Sukamto, and I. Mangisah. Healthy meat production of broiler fed microparticle-protein diet with inclusion of inulin derived from dahlia tuber extract. IOP Conf. Ser. Earth Environ. Sci. 292: 1-6, 2019.

Suthama, N, and P. J. Wibawa. Amino acids digestibility of pelleted microparticle protein of fishmeal and soybean meal in broiler chickens. J. Indonesian Trop. Anim. Agric. 43(2):169-176, 2018. 